\title{
Growing our own: Characterizing food production strategies with five U.S. community-based food justice organizations
}

\section{FoodDignity}

\author{
Christine M. Porter* \\ University of Wyoming
}

Submitted March 30, 2017 / Revised July 24, September 11, and November 13, 2017 /

Accepted November 15, 2017 / Published online June 18, 2018

Citation: Porter, C. M. (2018). G rowing our own: Characterizing food production strategies with

five U.S. community-based food justice organizations. Journal of A griculture, Food Systems, and

Community D evelopment, 8(Suppl. 1), 167-185. https:/ / doi.org/ 10.5304/ jafscd.2018.08A.001

Copyright $\odot 2018$ by the Author. Published by the Lyson Center for Civic Agriculture and Food Systems. Open access under CC BY license.

\begin{abstract}
Community-based organizations (CBOs) leading the U.S. food justice movement have helped expand community food production. Understanding the nature of this work is one key to being able to more effectively support and expand it. The literature, however, contains little scholarly work characterizing production-related practices of food justice CBO s. To help fill that gap, this paper draws from participatory action research with five CBO s to identify and characterize their community food production activities and goals.

This research was conducted over five years, during a project called Food Dignity, using three main methods: digital storytelling; collaborative pathway modeling; and conventional case study methods that included interviews, participation and observation, and document analysis. These data
\end{abstract}

* Associate professor and Wyoming Excellence Chair of Community and Public Health; Food Dignity and Growing Resilience Principal Investigator; Division of Kinesiology \& Health, College of Health Sciences, University of Wyoming; 1000 East University Avenue, D epartment 3196; Laramie, WY 82071 USA; christine.porter@uwyo.edu sets were examined to identify what production activities the CBO s support and why they undertake them.

Results suggest that the CBO s invest in community food production in eight main ways. Five are directly related to food. Listed roughly in decreasing order of intensity and frequency of the activities, these are (1) growing vegetables and fruits, (2) supporting community gardens, (3) supporting individual gardeners, (4) supporting local farmers, and (5) fostering other kinds of food production. Additionally, three crosscutting strategies underpin all the $\mathrm{CBO}$ s' work, including community food production: (6) connecting people and organizations, (7) promoting community food

\section{Contributors and Supporting Agencies}

Blue Mountain Associates; Feeding Laramie Valley; Whole Community Project; East New York Farms!; Dig D eep Farms; and the USD A National Institute of Food and Agriculture.

\section{Funding Disclosure}

Food Dignity (http:/ / www.fooddignity.org) was supported by Agriculture and Food Research Initiative Competitive Grant no. 2011-68004-30074 from the U.S. D epartment of Agriculture's National Institute of Food and Agriculture. 
systems, and (8) integrating their activities with community (as opposed to food) at the center. The CBO s' goals for these activities are transformational, including achieving community-led and sustainable food security, health, and economic equity.

The CBO s' crosscutting activities and longterm goals point to supporting and assessing outcomes that include food production and access but are also nonfood related, such as leadership development and feelings of belonging or ownership. Their wide range of food production activities and social change goals need more support for expansion, trial and error, documentation, and assessment. In particular, intentionally supporting food justice CBO s in their crosscutting strategies, which are foundational and yet less visible and underfunded, may multiply the range and reach of their impacts.

\section{Keywords}

Home Gardens; Community Gardens; Community Farms; Public Health; Community Food Systems; Community Food Production; Food Justice; Community-based O rganizations; Communitybased Participatory Research (CBPR); Food Dignity

\section{Introduction}

The United States is a wealthy nation with more than enough food to supply the needs of all its residents (Food and Agriculture Organization of the United Nations [FAO ], 2002; Hiza \& Bente, 2007). However, in 2015, 12.7\% of households in the U.S. were food-insecure, and about a fifth of American children were growing up in households that were uncertain they will have enough to eat every day (Coleman-Jensen, Rabbitt, G regory, \& Singh, 2016). This problem of inequity is one of many problems in the U.S. food system that the food justice movement aims to help resolve

\footnotetext{
1 In this paper, my use of "we" denotes the larger Food Dignity co-investigation team, particularly those named in Table 1. Some of the data I analyzed for this paper are codified knowledge products in their own right, particularly digital stories and collaborative pathway models, authored by other co-investigators, as cited. O ur work was conducted as participatory action research, or community-based participatory
}

(Sbicca, 2012), by localizing healthy food production, among other things. With immediate goals that might include sharing healthy food, selling such food at low cost, equipping people with production and job skills, and/ or providing opportunities for income generation (D aftary-Steel, Herrera, \& Porter, 2016), many CBO s leading the U.S. food justice movement have been working to expand community food production.

Little scholarly work about production-related practices of individual CBO s, much less multiple ones, has been published. However, understanding the nature and purposes of this community food production work is foundational for knowing how to best support it, for informing strategy with evaluation, and for beginning to estimate its current and potential array of yields. To help build that foundation, this paper draws from over five years of action research with five such CBO s to identify and characterize their community food production activities. The research questions this paper addresses are: (1) how do these five CBO s support community food production work? and (2) what their goals are for that work?

We conducted this research as part of the Food Dignity project. Food Dignity was a five-year effort (2011-2016) to document, support, understand, and partially assess food system sustainability and security strategies employed by five CBO s in the U.S.: Blue Mountain Associates (BMA) in the Wind River Indian Reservation; Feeding Laramie Valley (FLV) in Laramie, Wyoming; Whole Community Project (WCP) in Ithaca, New York; East New York Farms! (ENYF!) in Brooklyn, New York; and Dig D eep Farms (DDF) in the unincorporated areas of Ashland and Cherryland in the San Francisco Bay Area of California. I was the principal investigator and lead academic collaborator in Food Dignity. ${ }^{1}$

In this paper, I use the phrase "community food production" to mean micro- and small-scale

research (CBPR). However, the research questions I ask of this multiproject data set and the analysis and conclusions here are my own. Thus, though I have checked my data uses, interpretations, and conclusions with co-investigators, and though this draws extensively on the wisdom, expertise, and work of others as cited, I am responsible for this work as sole author. 
work to produce food, especially, but not only, fruits and vegetables, for hyperlocal consumption- whether in the producers' own households or in the immediate geographic community - via share or sale. The production being "communitybased" means the food work is done for, by, and with community members to self-provision and/ or to reach explicit food justice goals (as opposed to solely as a business). All the CBO community food production work described in this paper is community-based.

\section{Literature Review}

Support of community-based food production is a social change strategy used in the U.S. community food movement that is striving for community food security, sustainability, justice, and sovereignty (Broad, 2016; Saul \& Curtis, 2013; Winne, 2008, 2010). Enabling people to grow some of their own food in home and community gardens has become a fixture of that work, and of some obesity prevention initiatives (Gatto, Martinez, Spruijt-Metz, \& Davis, 2017; Lawson, 2005; Zanko, Hill, Estabrooks, Niewolny, \& Zoellner, 2014). Supporting food gardening and other forms of community food production may take society a step closer toward food justice and food security, including because that enables consumers to also become producers (Allen, 1999). Although, as Allen notes, ensuring households have enough to eat every day should be the work of "a non-retractable governmental safety net" (Allen, 1999, p.117), the work of the food justice movement includes building food systems where fewer people need to use such a net.

Certainly, interest in gardening has been growing in the U.S. (Taylor \& Lovell, 2014). Today, over a third of U.S. households grow at least some of their own food, even if only herbs on a windowsill. From 2008 to 2013, the number of gardening households increased by $17 \%$ overall, driven largely by a $63 \%$ increase among the millennial generation (National G ardening Association, 2014).

As summarized below, a rapidly growing body of literature demonstrates a trio of positive outcomes from community production via home and community gardening in improving health, producing meaningful amounts of food, and providing ecosystem services.
In health benefits, a recent meta-analysis of 22 quantitative studies suggests that gardening has significantly positive effects on physical, mental and- especially for community gardens- social health (Soga, G aston, \& Yamaura, 2017). Additional studies that were not included in the metaanalysis, mainly because they used observational and/ or qualitative research designs, suggest health benefits of gardening may also include increased fruit and vegetable intake (Alaimo, Packnett, Miles, \& K ruger, 2008; Armstrong, 2000; Litt, Soobader, Turbin, Hale, Buchenau, \& Marshall, 2011; Meinen, Friese, Wright, \& Carrel, 2012; Twiss, Dickinson, D uma, Kleinman, Paulsen, \& Rilveria, 2003), reduced food insecurity (Baker, Motton, Seiler, D uggan, \& Brownson, 2013; Bushamuka, de Pee, Talukder, Kiess, Panagides, Taher, \& Bloem, 2005; Corrigan, 2011; Stroink \& Nelson, 2009), and increased social capital (Alaimo, Reischl, \& Allen, 2010; Armstrong, 2000; Twiss et al., 2003).

Gardens also yield meaningful amounts of food. The average yield rate across eight studies that have quantified harvests in home and community gardens is $0.6 \mathrm{lbs} / \mathrm{ft}^{2}\left(2.93 \mathrm{~kg} / \mathrm{m}^{2}\right)$ of growing space (author calculations from Algert, Baameur, \& Renvall, 2014; CoD yre, Fraser, \& Landman, 2015; Conk \& Porter, 2016; Gittleman, Jordan, \& Brelsford, 2012; Pourias, Duchemin, \& Aubry, 2015; Smith \& Harrington, 2014; Vitiello \& Naim, 2009; Vitiello, Nairn, G risso, \& Swistak, 2010). This approaches the yield rate of $0.67 \mathrm{lbs} / \mathrm{ft}^{2}$ $\left(3.27 \mathrm{~kg} / \mathrm{m}^{2}\right)$ estimated to be typical of vegetable farms (Seufert, Ramankutty, \& Foley, 2012).

Community food production also provides "ecosystem services," that is, benefits that people obtain from ecosystems (Millennium Ecosystem Assessment, 2005, pp. 1-2). These include "provisioning" services, such as of food and health, as described above. "Regulating" ecosystems services that gardens and community farms provide include preserving biodiversity, cycling nutrients, and enhancing water quality (Calvet-Mir, GómezBaggethun, \& Reyes-G arcía, 2012; Cohen \& Reynolds, 2015; Cohen, Reynolds, \& Sanghvi, 2012). Social and cultural services provided by community food production appear to include building social capital and self-efficacy (Firth, Maye, \& Pearson, 2011; Litt et al., 2011; Ober 
Allen, Alaimo, Elam, \& Perry, 2008) and cultural connection and continuity (Companion, 2016). Also, increasingly, community gardening is being recognized as a promising social change strategy (Altman et al., 2014; Hou, Johnson, \& Lawson, 2009; Nettle, 2014; Pudup, 2008).

This trio of health, harvest, and ecosystem service benefits of community food production suggests that better understanding production practices offers a rich and valuable arena for further action research to support and learn from this work.

Another, much smaller body of research considers the processes and practices of $\mathrm{CBO}$ s that support community food production, especially in community gardens. Some research has focused on operational processes and technical lessons for founding and managing community gardens through interviews and/ or surveys with stakeholders across multiple gardens (e.g., Armstrong, 2000; D rake \& Lawson, 2015; Saldivar-Tanaka \& Krasny, 2004) or via case studies with individual community gardens (e.g., Thrasher, 2016).

Most relevant to the research question in this paper, about how and why food justice CBO s in the U.S. support community food production, are the few case studies with CBO s and community garden projects that focus on $\mathrm{CBO}$ s' goals and how they work to reach them. Case studies with six urban community gardens in Seattle suggest that, if intentionally designed for these ends, such projects can promote individual empowerment, community connectedness, and regional networking ( $\mathrm{Hou}$, Johnson, \& Lawson, 2009). The Five Borough Farm action and research project has been cataloguing these and other outcomes-including those in health, harvest, and ecosystem services catagories reviewed above-from urban agriculture projects in New York City (Altman et al., 2014; Cohen, Reynolds, \& Sanghvi, 2012). Finally, three case studies with three different food justice CBO s document anti-oppression ideology that underpins each CBO's mission and drives its activities. These studies were with the People's Grocery in O akland, California (Sbicca, 2012), Community Services Unlimited in Los Angeles, California (Broad, 2016) and the D etroit Black Community Food Security Network in Michigan (White, 2011). Each of these organizations intentionally frames how local histories of oppression shape their communities. Each also uses food, including food production, as a way to help community members provide for themselves while connecting with one another and growing power in order to reshape their communities.

The research presented here substantiates and expands upon this literature by being the first to characterize the activities, strategies, and drivers of multiple U.S.-based food justice CBO s in fostering hyperlocal, community-based food production.

\section{Methods}

Results in this paper derive from research conducted as part of the Food D ignity action, research and education project. Food Dignity was funded over five years with nearly US\$5 million from the USD A's National Institute of Food and Agriculture. It began in 2011 as a partnership between the University of Wyoming, Cornell University, and five food justice CBO s (BMA, FLV, WCP, ENYF! and DDF). When sketching the design for this project in 2010, I invited each of these CBO s to collaborate. I issued these invitations with an intent to maximize variation in geographic, institutional, historical, and community contexts, while also attending to practical travel considerations. Each accepted my invitation and then participated in codesigning our action research. Table 1 provides introductory information about each CBO .

I derived the findings in this paper about CBO food production activities and goals by applying a production-specific lens to the extensive case study data and development that anchor our research methods in Food Dignity.

The methods and data I used in this research are:

- E x tensively using conventional case study approaches (Y in, 2009), including conducting about 200 stakeholder interviews, extensive insider and outsider participation and observation, and primary and secondary document analysis. These overall methods are described in detail elsewhere (Porter, 2018a). Having frequently read and re-read these materials over the course of the 
Journal of Agriculture, Food Systems, and Community Development ISSN: 2152-0801 online

https:/ / www.foodsystemsjournal.org

Table 1. Summary Characteristics of the Food Justice CBO Partnersa in Food Dignity

\begin{tabular}{|c|c|c|c|c|c|}
\hline & Dig Deep Farms (DDF) & $\begin{array}{l}\text { Blue Mountain Asso- } \\
\text { ciates, Inc. (BMA) }\end{array}$ & $\begin{array}{l}\text { Feeding Laramie Valley } \\
\text { (FLV) }\end{array}$ & $\begin{array}{l}\text { yWhole Community } \\
\text { Project (WCP) }\end{array}$ & $\begin{array}{l}\text { East New York Farms! } \\
\text { (ENYF!) }\end{array}$ \\
\hline $\begin{array}{l}\text { Umbrella } \\
501(c)(3) \\
\text { organization }\end{array}$ & $\begin{array}{l}\text { Deputy Sherriff's } \\
\text { Activities League } \\
\text { (DSAL) }\end{array}$ & $\begin{array}{l}\text { BMA is incorporated } \\
\text { directly }\end{array}$ & $\begin{array}{l}\text { Action Resources } \\
\text { International (ARI) }\end{array}$ & $\begin{array}{l}\text { Cornell Cooperative } \\
\text { Extension of } \\
\text { Tompkins County }\end{array}$ & $\begin{array}{l}\text { United Community } \\
\text { Centers }\end{array}$ \\
\hline Location & $\begin{array}{l}\text { Ashland/ Cherryland } \\
\text { areas, Alameda } \\
\text { County, CA }\end{array}$ & $\begin{array}{l}\text { Ft. Washakie, Wind } \\
\text { River Indian } \\
\text { Reservation, WY }\end{array}$ & $\begin{array}{l}\text { Laramie, Albany } \\
\text { County, WY }\end{array}$ & $\begin{array}{l}\text { Ithaca, Tompkins } \\
\text { County, NY }\end{array}$ & $\begin{array}{l}\text { East New York, } \\
\text { Brooklyn, NY }\end{array}$ \\
\hline Founding year & 2010 & $\begin{array}{l}2003 \text {; in Wind River } \\
\text { since } 2008, \text { started } \\
\text { food work in } 2010\end{array}$ & 2009 & $\begin{array}{l}2006 \text { (ended in } \\
2016 \text { ) }\end{array}$ & 1998 \\
\hline $\begin{array}{l}\text { \# year-round } \\
\text { employees in } \\
\text { early } 2015^{b}\end{array}$ & $\begin{array}{l}\text { Approx. 10, some } \\
\text { with shared DSAL } \\
\text { responsibilities }\end{array}$ & 2 part-time & $\begin{array}{l}2 \text { full-time (including } \\
\text { ARI responsibilities) } \\
\text { + varying part time }\end{array}$ & 1 full-time & 7 full-time \\
\hline $\begin{array}{l}\text { Main co- } \\
\text { investigators }\end{array}$ & $\begin{array}{l}\text { Capt. Marty } \\
\text { Neideffer, Hilary } \\
\text { Bass, Mike Silva, Pac } \\
\text { Rucker, Rashaad } \\
\text { Butler ( } \& \text { Hank } \\
\text { Herrera until 2013) }\end{array}$ & $\begin{array}{l}\text { Dr. Virginia Sutter, } \\
\text { Jim Sutter, Etheleen } \\
\text { CPotter }\end{array}$ & $\begin{array}{l}\text { Gayle Woodsum, } \\
\text { Lina Dunning, Reece } \\
\text { Owens }\end{array}$ & $\begin{array}{l}\text { E. Jemila Sequeira, } \\
\text { Damon Brangman, } \\
\text { Monica Arambulo }\end{array}$ & $\begin{array}{l}\text { Sarita Daftary-Steel, } \\
\text { Daryl Marshall, David } \\
\text { Vigil }\end{array}$ \\
\hline Mission & $\begin{array}{l}\text { Provide access to } \\
\text { healthy food and } \\
\text { jobs in our com- } \\
\text { munity where access } \\
\text { to both has } \\
\text { historically been } \\
\text { limited }\end{array}$ & $\begin{array}{l}\text { Provide quality } \\
\text { programming and } \\
\text { professional } \\
\text { expertise to help } \\
\text { meet the health and } \\
\text { human services } \\
\text { needs of the rural } \\
\text { and urban } \\
\text { communities of } \\
\text { Indian Country }\end{array}$ & $\begin{array}{l}\text { Community based, } \\
\text { designed and led } \\
\text { work for sustainable } \\
\text { food security and an } \\
\text { equitable, just and } \\
\text { sustainable food } \\
\text { system in Albany } \\
\text { County, Wyoming } \\
\text { (vision) }\end{array}$ & $\begin{array}{l}\text { Facilitate a collab- } \\
\text { orative effort of } \\
\text { organizations and } \\
\text { individuals to } \\
\text { support the health } \\
\text { and well-being of } \\
\text { everyone in Tomp- } \\
\text { kins County; be a } \\
\text { place of dialog and } \\
\text { action for all the } \\
\text { communities that } \\
\text { make up Tompkins } \\
\text { County }\end{array}$ & $\begin{array}{l}\text { Organize youth and } \\
\text { adults to address } \\
\text { food justice in our } \\
\text { community by pro- } \\
\text { moting local sus- } \\
\text { tainable agriculture } \\
\text { and community-led } \\
\text { economic develop- } \\
\text { ment }\end{array}$ \\
\hline Website & $\underline{\text { http:// digdeepfarms. }}$ & $\begin{array}{l}\underline{\text { http:// bluemountain }} \\
\underline{\text { associates.com }}\end{array}$ & $\begin{array}{l}\underline{\text { http:// feedinglaramie }} \\
\underline{\text { valley.org }}\end{array}$ & $\begin{array}{l}\frac{\text { https:// www.food }}{\text { dignity.org/ whole- }} \\
\text { community-project }\end{array}$ & $\begin{array}{l}\text { http:// eastnewyork } \\
\text { farms.org }\end{array}$ \\
\hline
\end{tabular}

a The other partners, in addition to these five CBOs, were the University of Wyoming, Cornell University, and Action Resources International. Ithaca College and the University of California, Davis, also collaborated.

$\mathrm{b}$ The CBOs engage, hire, support, and/ or mentor additional people as volunteers, interns, temporary workers, seasonal employees, and project-specific leaders. For example, ENYF! mentors 20 to 30 youth interns each year, BMA engages summer market managers, FLV hires interns and VISTA associates, DDF supervises interns placed via criminal justice partnerships, and WCP supported (financially and otherwise) multiple community leaders in specific projects each year.

project, I started this research by sketching lists of the production-related activities that each CBO does. I then re-read my own and other co-investigators' field notes; interview transcripts that contained any variation of the word "garden," "farm," or "product"; and annual reports supplied by each CBO about their Food D ignity-related work, to catalogue and characterize the scope of these activities. Finally, I grouped activities by type, yielding the eight categories presented in the results. 
- C onsulting the F ood D ignity C ollaborative Pathway M odels that were developed with each CBO . Collaborative pathway modeling is a form of participatory inductive program modeling for surfacing and articulating theories of change underlying a CBO's programs and change initiatives (Hargraves \& Denning, 2018, in this issue). The resulting models present the CBO s' activities and link each activity, via a spaghetti-like web of arrows, to short-, medium-, and long-term outcomes. Pathway model contents correspond to columns in conventional logic models but add detailed connectivity between activities and outcomes. The five CBO collaborative pathway models are available online (Hargraves \& D enning, 2017). In the analysis for this paper, I simply used the models as designed, tying each production activity to the goals each CBO has for it by tracing the arrows.

- Relistening to first-person digital stories. D uring a 2015 workshop with the organization now called StoryCenter, 12 community partners and four academic partners each produced a roughly two-minute story about her or his journey to food justice and Food Dignity work. The full playlist is available online (Food D ignity, 2015). For this research, I relistened to the 12 community investigator-authored stories, and reread transcripts of them, to identify themes of food production activities and outcomes.

- Reviewing records of minigrants that the CBO s awarded to members of their communities. Part of the scope of work and subaward that each CBO led and managed as part of the Food Dignity partnership was to develop, implement, support, and track a minigrant program that supported community member proposals for improving their local food system. At the time of this study, I had up-to-date records of 86 minigrant projects awarded by the five CBO s, representing a total of just over US\$110,000 in awards. I re-reviewed these to identify which were related to community food production and then to characterize the focus of each production-related project. The results below include summaries of what kinds of production projects $\mathrm{CBO} s$ supported with these minigrant funds.

The results reported below emerged from these multiple qualitative methods, re-applied or analyzed through the narrow lenses of characterizing the food production activities and goals of the five $\mathrm{CBO}$ s.

\section{Results}

Each of the five CBO s (BMA, FLV, WCP, ENYF, and $\mathrm{DDF}$ ) has heavily invested in supporting community food production. For example, $65 \%$ of funded minigrant projects (i.e., 56 of the 86 analyzed, and approximately as a percentage of total dollars awarded) were invested in food production, including four production-related education projects. The average production-related award was US $\$ 1,339$. A mounts ranged from US\$156 for a beekeeping education project in Ithaca, New Y ork, to US \$4,299 for materials and labor to convert a large home yard into a production garden and then grow produce for the Laramie community.

This section summarizes the main production and production-support activities led by each CBO, which I characterize in eight categories. Five are relatively discrete food production strategies: producing vegetables and fruits, supporting community gardening, supporting individual gardeners, supporting farmers, and supporting other kinds of food production. Of these five, growing food is the most resource-intensive in terms of the quantity of labor, land, and material inputs required. The other three are crosscutting strategies that underpin all the work the CBO s do: connecting, mentoring, and networking; promoting food justice; and integrating all activities around community and people (as opposed to around food and food systems). The leaders of the CBO s invest much of their time in this complex trio of strategies, which demand great skill, expertise, and practical wisdom.

In each category below, I describe the production work led by each CBO roughly in order of how centrally that work features in the 
organization's activities, with the most prominent work mentioned first. I use present tense whenever the activities are ongoing at the time of this writing.

In the final section of these results, I characterize these eight activities, especially the three crosscutting ones, in the context of the CBO s' long-term goals.

\section{Producing vegetables and fruits to sell and share}

All but one of the five CBOs have produced vegetables and fruits to sell or to share in their communities. Three (DD F, ENYF, and FLV) systematically grow food. As outlined later, the $\mathrm{CBO} s$ engage in three crosscutting activities to garner, grow, and develop the substantial resources required to produce food. This especially includes gaining access to land (usually public) at low or no ongoing direct cost to the organization.

Producing and locally selling food is DDF's core activity. Of the five CBO s participating in Food Dignity, D D F manages by far the most production land and, based in California, enjoys the longest growing season. Since its founding in 2010 with several small and scattered sites, DD F has expanded and consolidated into 8 acres (3 hectares) on three farms: the small and original Firehouse Farm near their offices in unincorporated Cherryland/ Ashland, the nearby Pacific Apparel lot with raised beds and a greenhouse, and City View Farm. City View is within the gates of a juvenile detention facility in San Leandro. After resolving multiyear struggles with sheep getting into the fields, water supplies, and hillside planting, City View is now D D F's biggest farm and includes a successful orchard. DD F sells its harvests via a community supported agriculture operation (CSA) and, as of 2014, at D D F farm stands.

ENYF!'s first public activity was a farm and garden stand in 1998. By 2000, it had converted a half-acre (0.2 ha) lot next to its host organization's building (United Community Centers, or UCC) into the UCC Youth Farm. UCC staff and community members had been slowly cleaning up the lot since 1995. Harvests are sold at the ENYF! Saturday market and Wednesday farm stand. In 2015, in collaboration with a local public housing community, ENYF! also co-founded the half-acre
Pink Houses Community Farm that shares harvests with residents.

FLV, in part to expand supply for the freshfood sharing program it had started in 2009, first began growing food in community garden plots and private home yards of supportive community members in 2011. O nce they leased their first office space in a historic Laramie city park building in 2013, FLV also planted $550 \mathrm{ft}^{2}\left(51 \mathrm{~m}^{2}\right)$ around the building; it built a hoop house in 2014. In 2016, the organization also began growing food at the Feeding Laramie Valley Farm in a one-acre (0.4 ha) field, including another new hoop house, at the local county fairgrounds.

BMA became directly involved in food-related work in 2010, including by piloting a fruit tree orchard and hoop house on Tribal farmland with support from a specialty crops grant. However, the former succumbed to loose cattle (mirroring herbivore challenges D D F faced at City View before installing an electric fence) and the latter to high winds.

BMA and FLV both currently seek to establish multi-acre community farms, and DDF continues to expand production areas. Threats to land access has meant that ENYF! has focused on protectingits existing production land in East New Y ork, in addition to its expansion work, such as with the Pink Houses collaboration. WCP, having had only one staff member year-round, is the one CBO of the five that did not produce food directly.

\section{Supporting community gardening}

Four of the five CBO s (all but D DF) have been heavily involved in founding and/ or supporting community gardens where individuals from the area can grow their own food at very low or even no cost, share growing skills and knowledge, and create and maintain green spaces in their neighborhoods. For example, 20 of the 56 minigrants awarded for food production projects went to support community-based gardening work, including home-yard-based gardens for community use, a demonstration garden, and several season-extension investments. In addition, as described in this and the next section, some of the CBO s provide formal opportunities for gardeners to share or sell their harvests. 
ENYF! founded Hands \& Heart Garden in 2006 on an abandoned lot, with support from the New York City housing department and the GreenThumb program of the city parks department. Today, with continued support from ENYF, 30 gardeners grow food there, mostly for their households and in part to supply diverse produce options at ENYF! market stands. G ardeners whom ENYF! supports are encouraged to sell some of their harvest at the market if they have enough. To facilitate this, ENYF! youth interns staff a "Shared Table" where growers can sell their harvests without needing to host their own stand. Gardeners can even invite the interns to harvest and deliver produce to the market on their behalf. D epending on their labor contributions, $40-80 \%$ of the proceeds return to the grower. Since 2013, ENYF! has also been experimenting with a new growing space with several of its most prolific growers to supply the market and for senior growers to mentor youth. ENYF! also collaborates with organizers of 25 of the neighborhood's other community gardens (of which East New York has more than any other New York City neighborhood). This has included providing technical and material support and assisting some individual gardeners.

Starting in 2009, WCP played the central role in founding the $\mathrm{G}$ ardens 4 Humanity network of community members aiming to promote empowerment through urban gardening and local farm connections. Projects have included support for communal growing spaces at a community center and at a church, and help with founding new community gardens with three public housing complexes. WCP also extensively supported one community leader in establishing an intergenerational gardening project at an Ithaca, NY, senior housing complex and another leader in expanding a community garden in a rural village near Ithaca (D ryden, NY).

In Laramie, in 2010, FLV helped Laramie Rivers Conservation District to develop the first community garden in a city-run park. FLV then managed the garden for its first seven years, with 16 member gardeners. In 2015, FLV also began planning with community members for another city park garden on Laramie's west side, which is underserved with public infrastructure and does not have a grocery store. It expects to break ground soon.

DDF started as an idea discussed among a small group of people in 2009, some of whom wanted to focus on gardening. However, inspired in part by Van Jones's work (2009), DD F ended up focusing on professional farming instead as a jobcreation and crime-prevention strategy.

In the dry and highly rural communities of Wind River Indian Reservation, several community garden projects have been founded, floundered, and failed over the years. BMA supported one community leader with a minigrant in an attempt to resurrect one of those projects in 2011, but this was unsuccessful due to both water access and travel distance challenges. BMA has focused its gardening support on home gardeners, taking advantage of the fact that most families have plenty of land and sufficient water access at home, often with extended families able to provide the mix of labor and expertise needed to garden.

\section{Supporting individual gardeners}

The same four CBO s (BMA, FLV, ENYF, and WCP) have also invested heavily in supporting individual gardeners in their communities, beyond their community garden-level work, including by providing supplies, technical assistance, labor assistance, and education. For example, 20 of the minigrant awards analyzed went to support establishing or expanding home gardens to enable families to self-provision, share with community members, and/ or diversify and expand produce supplies at local markets. These ranged from one US $\$ 400$ minigrant to establish a new small home plot up to a few US $\$ 2,000$ awards made for establishing large gardens (e.g., quarter acre or $0.10 \mathrm{ha}$ ) and greenhouses.

Since 2011, with minigrants supported via Food Dignity and then as part of an expanding food justice research partnership with me, BMA has provided 70 families with the supplies, labor, and technical support to create and grow new home food gardens. Between 2018 and 2020, they plan to support another 70 families in installing new home gardens as part of a project we call Growing Resilience, funded by the National Institutes of Health (Blue Mountain Associates et al., 
2017). Similarly, FLV has fully supported about 35 households in Laramie in establishing new home food gardens. FLV has also helped dozens more with supplies, technical advice, and moral support provided through home visits (including me, when I was about to give up on trying to make anything grow at an elevation of $7200 \mathrm{ft}$. (2,195 m) in Wyoming) and hundreds more in public workshops and events that it organizes. In the nearly 20 years since its founding, ENYF! increasingly has supported home gardeners by hosting community-led workshops, sharing supplies such as trellising nets and cover crop seeds, and pairing ENY F! youth interns with older gardeners to share labor, skills, and stories. ENY F! supports about 20 home gardeners each year with the internship-matching and 150 to 200 more with workshops and materialsharing (in addition to supporting gardeners tending individual plots at community gardens). WCP supported improving access to gardening in communities struggling with low incomes, largely via the Gardens 4 Health network mentioned above. This network has continued even though WCP has not. In addition to supporting development of community gardens at the public housing locations mentioned earlier, the network has helped several people create gardens at their homes. DDF, as described above, focuses on community farming rather than gardening. However, it does also aim to foster home food production via example and through some public education activities, as outlined in its collaborative pathway model (D DF, Neideffer, Hargraves, \& D enning, 2017).

\section{Supporting local farmers}

WCP was the only one of the five $\mathrm{CBO}$ s who devoted substantial time to farmer support. After expanding from a project focused on childhood obesity prevention to one more broadly focused on food justice in 2008, WCP focused on helping to diversify who has opportunities to farm. This work included supporting local farmers of color, including at Roots Rising Farm and Rocky Acres Community Farm, and collaborating with $\mathrm{G}$ roundswell, a local farm incubator. This was part of an explicit goal in WCP's collaborative pathway model of "increased farming and food production by people of color and people of limited resources" (WCP,
Sequeira, Hargraves \& Denning, 2017). WCP was the only CBO to award a minigrant to a vegetable farm, providing US $\$ 2,000$ to build a greenhouse for both production and community education activities.

The other four CBO s support local farms by purchasing from them or by providing sales venues by hosting farmers markets. DDF supplements its CSA shares and farm-stand offerings with purchases from other local, organic farms as needed through a distributor called Veritable Vegetable. FLV fundraises to buy from local producers, in addition to taking donations, to supply its FLV Shares distribution programs. ENYF! and BMA host farmers markets with low farmer vendor fees (US\$40 and US\$6 per market, respectively, in 2016, and half that for gardeners and other smaller vendors) so that local and regional producers can sell their harvests in those communities.

\section{Supporting other kinds of community food production}

As a much less central activity, the $\mathrm{CBO}$ s have supported community members in producing food beyond fruits and vegetables. This has been mainly through providing financial support via minigrants. CBOs made nine awards in this area, almost entirely to support bee or poultry husbandry. CBO s have also provided avenues to sell resulting food products, such as honey and eggs, and/ or helped with other kinds of food production via technical support and education. Unlike in the previous four sections, the activities described here are a nearly complete catalogue rather than an array of representative examples.

BMA helped a family expand its flock of chickens to yield eggs beyond its family members' own consumption needs to sell at the Tribal farmers market. FLV enabled a household to improve and expand the conditions for a small turkeyraising operation. ENYF! has supported a local beekeeper in not only expanding her production but, with minigrant funding, in teaching others how to establish their own hives and providing community access to a honey extractor. East New Yorkers can also sell their honey and other homemade value-added products (that are legal for public sale under health codes), such as hot sauces, 
at the intern-staffed Shared Table mentioned above. DDF has experimented in the past with honey production, and once briefly considered trying goat husbandry, although it has decided to focus on produce production for now. DDF has also been exploring options for making valueadded products from its fruit and vegetable harvests and for catering. WCP, in activities entwined with the mentoring described below, provided market-research support for a local farmer to expand his microbusiness in selling juices made from his harvests.

\section{Connecting (networking, convening and mentoring)}

Leaders in all five CBOs invested substantial time in foundational strategic activities that few funders pay for, measure, or count: networking, convening, and mentoring. These connecting activities enable all their other work, including - although not only - when they result in formal partnerships and collaborations. For the smallest of the CBO s, particularly WCP, the dominant approach for effecting food system change is helping to enable others to lead programs and projects.

In the case of community food production, networking is particularly important to securing and keeping access to land; every instance of securing land for food production for all five CBO s resulted from their broad, intentional, and constant networking. For example, when DDF leaders invited an academic Food Dignity coinvestigator to help them document and characterize their network, they provided her a list of 150 individual contacts across over 60 organizations with whom they had collaborated during their first five years of operation. These networks are how they obtained access to the 8 acres of land for their production operations.

Mentoring work includes ENYF!'s longstanding youth internship program (D aftary-Steel, 2015) and FLV's internship programs, which support the CBO s' production capacity while passing on expertise in growing produce. BMA convenes the gardeners it supports to share experience and seeds. WCP invested heavily in mentoring and professional development with grassroots community leaders, including, for example, by supporting a community garden organizer in developing her permaculture expertise. DDF joined a regional farmer field school for its farmers' professional development (Meek et al., 2017).

This constant and intentional connecting has also sometimes fostered food production beyond securing land access and skill development. For example, in August 2009, WCP convened several community leaders to discuss a funding opportunity for racial healing and equity efforts. Though the group eventually decided not to apply, at that meeting two of the participants met for the first time and discovered that they shared a dream of helping to connect youth to farming and-across race, class, and geographic lines- to one another. By 2010, in collaboration with many others and with further support from WCP, they founded the Youth Farm Project. The Y outh Farm began in partnership with local family farms and now manages its own 10 acres (4 ha), with half in production each season.

\section{Promoting (advocating; reframing; and documenting, generating, and sharing knowledge)}

As with the connecting activities, leaders in all five CBOs also invest heavily in activities to generate, maintain, and expand public support, including policy and funder support, for equitable food systems and social equity. As with the connecting activities described above, promoting activities support and enable all the others, including securing access to land for food production.

Some of this has focused on documenting processes and outcomes of their current activities, such as producing the pathway models used in this research, quantifying food harvests, and-in new projects in Wyoming - assessing health impacts of food gardening. Some has been via education, with all five CBOs having hosted formal visiting groups, such as from schools and universities, and also scores of informal visitors, in addition to hosting or cohosting workshops, film nights, celebration events, and other food justice gatherings. Some of this work has been documenting the food (in)justice histories in their communities and using multiple forms of disseminating that knowledge and framing. For example, see the redlining 
discussion in (D aftary-Steel \& G ervais, 2015), digital stories produced by several CBO-based Food Dignity co-investigators (Brangman, 2015; Neideffer, 2015; Sequeira, 2015), and comments by other Food Dignity partners in a minidocumentary about producing those stories (Luotto, 2015).

To illustrate the breadth of the CBOs' promotional activities, here is an additional example from each. O ne reason ENYF! agreed to partner in the Food D ignity project was its interest in documenting food production quantities. They wanted to collect this data to illustrate one of the many ways their work benefits East New York. As land pressures have increased, they also have joined and helped form increasingly formal advocacy partnerships, including the Coalition for Community Advancement in 2015. FLV has worked extensively with local government to secure public acres for scaling up community food production, using results from our harvest quantification research (Conk \& Porter, 2016) to prove that significant production is possible even in Laramie's short growing season. This data was helpful in securing the acre for the Feeding Laramie Valley farm. In a broader policy example, the director of WCP joined in discussions to form a county food policy council by convening a series of Community Food Security Dialogues in 2010 where the idea first gained traction. In 2015, she was elected to serve as a member of the first council. DDF, as a local government CBO collaboration, has reframed Alameda County criminal justice as crime prevention and restorative justice work, with job creation through food production being one strategy. Its work earned D D F the California State Association of Counties innovation award in 2014. BMA, the first Tribal-led CBO doing food work in Wind River, has put food sovereignty on the map with the Northem Arapaho and Eastern Shoshone nations, both with the Tribal governments and the people.

\section{Integrating food system work around people and community (not around food)}

As an academic who studies food systems, I tend to use a lens that focuses on food, including with the food production analysis in this paper. However, the leaders of all five CBOs center their focus on people and communities, not food, and they each integrate their food system work around that. For example, the way all five organizations articulate the historical and current systemic contexts of current food injustice, as described above, put community at the center of their work, rather than food.

In another example of this people-rather-thanfood focus, FLV names one arm of its work FLV Shares, where the goal is to enable people to "share the best of what southeastern Wyoming has to offer" with one another, whether that be fresh food, land for food production, knowledge, money, mentorship, and/ or labor. In other words, the organizing principle for these activities is sharing within the community, rather than food. Further illustrations of this integration around investing in community are embedded in the final results section below, which also outlines why these five food justice CBO s support community food production in these eight ways.

W hy grow our own? Transformation These CBO s support community-based food production in these eight ways, especially the last three crosscutting ways, to achieve not only food security, but also sovereignty (La Via Campesina, 2010). This includes striving for individual and collective health, power, pride, strength, and sense of belonging. For example, long-term goals that the $\mathrm{CBO}$ s articulate in their collaborative pathway models include "reclaiming, restoring, and developing food sovereignty on our reservation" (BMA, Sutter, Hargraves, \& D enning, 2017); a "stronger, healthier, more just, and sustainable community" (ENYF, Vigil, Hargraves, \& D enning, 2017); "increased collaborative efforts and leadership development in the community, strengthened community fabric" (D D F et al., 2017); "increased representation and power of underrepresented groups in local food system decision-making" (WCP et al., 2017); and "increased community connections, sense of belonging, worth and possibility" (FLV, Woodsum, Hargraves, \& D enning, 2017). A transformative short-term goal named for FLV Shares activities mentioned above is "softening lines between giver and receiver" (FLV, Woodsum, Hargraves, \& D enning, 2017). 
In two of the communities, the CBO s support community food production to restore and share culturally and spiritually important foods. BMA in Wind River Indian Reservation is helping community members restore traditional varieties of Indian corn and re-establish chokecherries. As noted in their collaborative pathway model, BMA is intentionally supporting gardeners so that "traditional foods and ways are brought into current community life" (BMA et al., 2017). Gardeners supported by ENYF! in Brooklyn grow culturally important foods such as callaloo, long beans, and bitter gourd. As their pathway model notes, this forms part of that CBO's intentional support to increase "production of specialty crops valued by diverse nationalities in East New York" (ENYF! et al., 2017).

All five CBO s partners support food production to "grow" people and community. Both WCP and ENY F! intentionally build intergenerational, mutually beneficial relationships by matching teens with local elders who provide mentorship while receiving help with their gardening (Brangman, 2017; D aftary-Steel \& G ervais, 2015). FLV works with food-insecure communities who define their fresh food access needs and help FLV design their programs for growing, buying, and, accepting donations of local, fresh fruits and vegetables. This provides access to, as FLV founder Gayle Woodsum puts it, "the best of what we have," while demonstrating a dignitypromoting ethic of "we" as an alternative to a charity stance of "we" give to "them" (FLV et al., 2017; see also Poppendieck, 1998). O ne of D DF's long-term goals is to "create hope, break bonds of dependency, build self-reliance (transformed individual lives)" (DDF et al., 2017). As midterm outcomes, BMA strives for "increased friendships and socializing between people on and off the reservation," (BMA et. al, 2017) and WCP for "emergence of new community food system leaders from underrepresented communities" (WCP et al., 2017).

However, frontline leaders in this CBO work also know that home and community-scale food production offers only one, important but insufficient, strategy for healing and transformation in the face of systemic disinvestments, poverty, and racism (D aftary-Steel, Herrera, \& Porter, 2016). For example, the community organizer who led WCP from 2008 to 2016 shares the story of her brother's declining health and early death in her digital story:

He had tried to take care of himself. He had been growing veggies on his patio in Brooklyn before it was cool to be sustainable. But trying to live on disability after work-related injury made it impossible for him to eat well, no matter how many tomatoes he produced. (Sequeira, 2015, 1:39-1:58)

Another of the storytellers, a farmer at D DF, tells of growing up in Oakland housing projects with no access to fresh food, then learning to farm in Ashland/ Cherryland at DDF and returning to live in the same housing. This farmer (storyteller) notes that he can now share his food production knowledge with his community, but that his O akland neighborhood still has no access to fresh food (Rucker, 2015).

Both the potential and the limits of individuals producing food on their own are also illustrated in the digital story told by a leader who works with BMA. She describes planting cucumbers for her young nephew, who asked her to make pickles (Potter, 2015). However, since he ate every cucumber fresh as soon as it was ripe on the vine, she had to tell him that meant no homemade pickles that year. He asked, "we can grow some again next year, right, aunty?" She assured him, "Yes, we can" (Potter, 2015).

\section{Discussion}

This paper describes how and why five U.S. food justice CBO s support community food production as part of their larger work to improve the equity and sustainability of their local food systems, and to foster health and transformation. Their main activities specific to food production involve both directly producing food-mostly vegetables and some fruits- and supporting others in producing food, especially in home and community gardens. Each CBO also supports local farmers, mostly in minor ways. None produces food directly via animal husbandry, though some have supported 
community members who do so. Foraging and gleaning were not part of their activities during the time of the Food Dignity collaboration. As articulated in their collaborative pathway models, all of the CBO s choose and organize their activities with and for their communities.

In addition, all five $\mathrm{CBO}$ s have devoted substantial resources to three crosscutting strategies that underpin all the work they do: (1) connecting and mentoring people and organizations; (2) promoting community food systems; and (3) integrating their strategies with community (versus food) at the center. In other words, they do community organizing for social justice. Their production activities are part of social change strategies for reaching transformational goals.

If viewing this social change work within the "warrior, builder and weaver" categories of food system resistance, reconstruction, and connection work outlined by one group of food system activist and scholars (Stevenson, Ruhf, Lezberg, \& Clancy, 2007, p. 33), these organizations invest most heavily in building local food alternatives with, by, and for their communities and in local weaving work for strengthening and deepening civic engagement and connectedness. Their explicit "warrior" work is less frequent and tends towards hyperlocal mobilizing to foster or to protect their building work, in particular regarding land access for food production.

Another way of illuminating the social change work of the CBO s is to view it through the food regime and food movement framework developed by Holt-G iménez and Shattuck, which categorizes food system approaches by the politics underlying the work. They outline the range of options from neoliberal or reformist on the "corporate food regime" side, to progressive or radical on the "food movements" side (2011, p. 117). In this framework, the long-term goals and the organizing activities of the $\mathrm{CBO}$ s range from progressive to radical in striving for food justice and food sovereignty.

Because the empirical literature about the work of CBO support for community food production is so thin, this paper adds substantially to it by simply categorizing and characterizing activities and goals in $\mathrm{CBO}$ s' production work. These findings are consistent with the themes of empowerment, connectedness, and networking found in Seattle community garden projects, for example (Hou, Johnson, \& Lawson, 2009), and with the antioppression approaches of the food justice CBO s People's Grocery, Community Services Unlimited, and D etroit Black Community Food Security Network (Broad, 2016; Sbicca, 2012; White, 2011).

Two implications of this work include: (1) in spite of having limited and mostly insecure resources, these $\mathrm{CBO}$ s lead and facilitate a wide range of food system activities in food production and beyond in their communities; and (2) since such CBO s are leading localization of food systems in the U.S., conducting more collaborative research to help understand, learn from, evaluate, and inform their work is important for fostering community food justice and food security.

In addition, less conclusively, another implication is that a food-focused lens that academics tend to apply (as I do in this paper to examine production) in understanding or assessing CBO food justice work may unduly limit the depth and accuracy of the view if used alone. In particular, it risks underestimating the core but less visible crosscutting strategies these $\mathrm{CBO}$ s take to transform their communities through food system work. If funders, evaluators, and other external stakeholders in these transformations do not see this organizing work, they will neither credit nor support it. Yet this crosscutting work in connecting, promoting, and integrating underpins and enables the more visible CBO activities, such as producing food. This is obvious to the CBO leaders, but often less so to outsiders. Consider, for example, a reflection from a community food system funder who was at first impatient in the face of what she realized was "largely invisible development" of relationships, networks, and mentoring, noting that she realized, "it takes time to develop this web- two to three years minimum and unless it is supported it grows weaker" (Feenstra, 2002, pp. 104-105).

\section{F uture Research}

Three important research questions within the frame of CBO support for community food production that this research does not address include: (1) what are the outcomes of these CBO 
production support activities? (2) how and how much are these outcomes distributed within a community? And (3) how much do the CBO support strategies and the community contexts shape these outcomes?

For example, in outcomes, what impacts does gardening have on food security? The quality of the evidence cited in the introduction is low, and none of the nearly two dozen garden studies included in a meta-analysis of quantitative health results included food security outcomes (Soga et al., 2017). This is a question we aim to help answer in the five-year trial with BMA and others, once it concludes in 2020 (Blue Mountain Associates et. al., 2017). I also outline outcomes from home and community gardening that we found in Food Dignity and related action research elsewhere in this issue (Porter, 2018b).

In distribution of outcomes, who benefits most from these production support activities? When I sent drafts of this paper to Food Dignity collaborators for review, Sequeira, the former director of WCP, noted:

I suggest that you elaborate more on how systemic racism and economic disadvantage thwart the possible advantages gardening can have in the lives of low-income communities and communities of color. Such a discussion could be framed within the context of limited choices for low-income households to garden - limited availability of environmentally safe places to grow, restrictions of the use of water needed to garden, limited educational venues for people to conveniently access resources, support and technical help and of course, the lack of policies that allocate safe and unused land for community use (e.g., land trusts). (E. J. Sequeira, personal communication, January $6,2017)$

In the literature, results from extensive household survey data in O hio underline Sequeira's observations about space and income constraints creating barriers to home gardening (Schupp, Som Castellano, Sharp, \& Bean, 2016). The extensive home and community gardening support that four of the five $\mathrm{CBO}$ partners in Food Dignity provide aim to help overcome both barriers, including with minigrants and with the full financial and technical support that FLV and BMA have been able to offer in the gardens-for-health trials that emerged as a next step from the Food Dignity collaboration. Also, all five organizations work intentionally to reduce disparities. However, the research reported here does not assess these important questions of distribution of benefits (Hallsworth \& Wong, 2015) nor the classist and racist contexts of the CBO s' work (Hilchey, 2015).

Finally, how can the reach and the outcomes of such food justice-oriented community food production work best be supported? And what are its limits? (Hallsworth \& Wong, 2013). The growing body of evidence that supports that food gardening offers substantial yields of multiple kinds, while empowering consumers to also be producers, suggests that their work deserves more explicit public policy and technical support. The CBOs investing in increasing community food production in community farms, most notably FLV, BMA, and DD F, are interested in conducting future action research to support and inform that work. In addition, supporting and assessing outcomes from the crosscutting, community-organizing strategies employed by the CBO s and assessing their impacts on outcomes- as opposed to outcomes from programs that narrowly focus on direct production activities - is an arena ripe for further research. We could not assess this in our work because all five CBO partners in Food Dignity did take such organizing approaches.

\section{Conclusion}

The community-based food production activities of these five CBO s focused mostly on producing vegetables and fruits directly for sharing or selling locally and on supporting community gardens and individual gardeners. To a lesser extent, they were involved in supporting other forms of food production, such as honey, eggs, or added-value processing, and in supporting local farmers. Using community organizing strategies, they connect, promote, and integrate all of the production and other food justice work they do to reach transformational goals of community-led food security, public health, and equity. 
The three crosscutting activities by each $\mathrm{CBO}$ - connecting people and organizations, promoting community food systems, and integrating their activities with community (as opposed to food) at the center - feature deeply and broadly in all aspects of their work. The foundational and lynchpin roles of these activities in enabling production and other direct food system work became clear to outsider partners only through years of this action-research partnership, aided by the collaborative pathway modeling process. We hypothesize that making direct investments in these crosscutting activities will translate into multiplying the range and reach of outcomes in the $\mathrm{CBO} \mathrm{s}^{\prime}$ hyperlocal community food production and other food system work. We and others should support and evaluate such strategies in future action research collaborations. Collaborative pathway modelling offers a framework for grounding such evaluation in the specificity, integrated complexity, and comprehensiveness of the goals of the work of these
CBO s (Hargraves \& D enning, 2018, in this issue).

In her digital story mentioned above, Potter assured her nephew that they could grow more cucumbers next year. The premise and the promise of the CBO-led food production work characterized here is that the more extensive and integrated our "we" is, then the more we can grow this year, next year, and for generations to come. Together we could all, perhaps, eat fresh cucumbers now and have pickles for later, too.

\section{Acknowledgments}

I would like to thank the action research teams of Food Dignity and Growing Resilience, including gardener-researchers of Team G ROW and Elisabeth "Livy" Lewis, and especially the communitybased researchers and leaders at each $\mathrm{CBO}$ who reviewed my use of our work here. Thanks also to Monica Hargraves and Cecilia D enning for their Collaborative Pathway Model work and for reviewing and advising on my use of those here.

\section{References}

Alaimo, K., Packnett, E., Miles, R. A., \& Kruger, D. J. (2008). Fruit and vegetable intake among urban community gardeners. Journal of N utrition E ducation \& B Behavior, 40(2), 94-101. https:/ / doi.org/ 10.1016/ j.jneb.2006.12.003

Alaimo, K., Reischl, T. M., \& Allen, J. O. (2010). Community gardening, neighborhood meetings, and social capital. Journal of Community Psychology, 38(4), 497-514. https:/ / doi.org/ 10.1002/ jcop.20378

Algert, S. J., Baameur, A., \& Renvall, M. J. (2014). Vegetable output and cost savings of community gardens in San Jose, California. Journal of the A cademy of N utrition and D ietetics, 114(7), 1072-1076. https:// doi.org/ 10.1016/ j.jand.2014.02.030

Allen, P. (1999). Reweaving the food security safety net: Mediating entitlement and entrepreneurship. A griaulture and H uman V alues, 16(2), 117-129. https:/ / doi.org/ 10.1023/ A:1007593210496

Altman, L., Barry, L., Barry, M., Englese, C., Kühl, K., Silva, P., \& Wilks, B. (2014). Five Borough Farm II: G rowing the benefits of urban agriculture in N ew Y ork City. New Y ork: D esign Trust for Public Space.

Armstrong, D . (2000). A survey of community gardens in upstate New Y ork: Implications for health promotion and community development. H ealth \& Plaœ, 6(4), 319-327. https:/ / doi.org/ 10.1016/ S1353-8292(00)00013-7

Baker, E. A., Motton, F., Seiler, R., D uggan, K., \& Brownson, R. C. (2013). Creating community gardens to improve access among African Americans: A partnership approach. Journal of $\mathrm{H}$ unger \& E nvironmental N utrition, 8(4), 516-532. https:/ / doi.org/ 10.1080/ 19320248.2013.816986

Blue Mountain Associates [BMA], National Heart, Lung, and Blood Institute, Eastern Shoshone Tribal Health, Action Resources International, National Institutes of Health, National Institute, of G eneral Medicinal Sciences, \& Wind River D evelopment Fund. (2017). G rowing resilience in W ind River Indian reservation (Identification No. NCT02672748). Retrieved from https:/ / clinicaltrials.gov/ ct2/ show/ NCT02672748

BMA, Sutter, V., Hargraves, M., \& D enning, C. (2017). Blue Mountain Associates: Food Dignity project - A collaborative pathway model [Image]. Retrieved from the Food Dignity website: http:/ / www.fooddignity.org

Brangman, D . (Producer). (2015). Roots rising. Paths to F ood D ignity [Video]. Retrieved from http:// www.youtube.com/ watch?v=JW40uOLVebU

Brangman, D . (Producer). (2017). Whole Community Project [Video]. Retrieved from http:/ / www.fooddignity.org 
Broad, G. M. (2016). M ore than just food: F ood justice and community change. O akland, CA: University of California Press.

Bushamuka, V. N., de Pee, S., Talukder, A., Kiess, L., Panagides, D., Taher, A., \& Bloem, M. (2005). Impact of a homestead gardening program on household food security and empowerment of women in Bangladesh. F ood \& N utrition Bulletin, 26(1), 17-25. https:/ / doi.org/ 10.1177/ 156482650502600102

Calvet-Mir, L., Gómez-Baggethun, E., \& Reyes-García, V. (2012). Beyond food production: Ecosystem services provided by home gardens. A case study in Vall Fosca, Catalan Pyrenees, Northeastern Spain. E ological E conomic, 74, 153-160. https:/ / doi.org/ 10.1016/ j.ecolecon.2011.12.011

CoD yre, M., Fraser, E. D ., \& Landman, K. (2015). How does your garden grow? An empirical evaluation of the costs and potential of urban gardening. U rban Forestry \& U rban G reening, 14(1), $72-79$.

https:// doi.org/ 10.1016/ j.ufug.2014.11.001

Cohen, N., \& Reynolds, K. (2015). Resource needs for a socially just and sustainable urban agriculture system: Lessons from New York City. Renewable A griculture and F ood Systems, 30(1), 103-114.

https:/ / doi.org/ 10.1017/ S1742170514000210

Cohen, N., Reynolds, K., \& Sanghvi, R. (2012). Five Borough F arm: Seeding the future of urban agriaulture in N ew Y ork City. New York: Design Trust for Public Space.

Coleman-Jensen, A., Rabbitt, M., G regory, C., \& Singh, A. (2016). H ousehold food searity in the U nited States in 2015. Economic Research Report No. (ERR-215), U.S. Department of Agriculture, Economic Research Service. Retrieved from http:/ / www.ers.usda.gov/ publications/ err-economic-research-report/ err173.aspx

Companion, M. (2016). Lessons from "The Bucket Brigade:" The role of urban gardening in Native American cultural continuance. In J. C. D awson \& A. Morales (Eds.), Cities of F armers: U rban A gricultural Practioes and Proesses (pp. 126140). Iowa City, Iowa: University of Iowa Press.

Conk, S. J., \& Porter, C. M. (2016). Food gardeners' productivity in Laramie, Wyoming: More than a hobby. A merican Journal of Public H ealth, 106(5), 854-856. https:// doi.org/ 10.2105/ AJPH.2016.303108

Corrigan, M. P. (2011). G rowing what you eat: D eveloping community gardens in Baltimore, Maryland. A pplied G eography, 31(4), 1232-1241. https:/ / doi.org/ 10.1016/ j.apgeog.2011.01.017

Daftary-Steel, S. (2015). G rowing young leaders in E ast N ew Y ork. Retrieved from https:/ / docs.wixstatic.com/ ugd/ c0c10a fb310ad357084e36939ded0b78c3b1c9.pdf

Daftary-Steel, S., \& G ervais, S. (2015). ENYF retrospective case study [Prezi]. Retrieved from https:/ / prezi.com/ kixjpppdqbqz/ enyf-retrospective-case-study/

D aftary-Steel, S., Herrera, H., \& Porter, C. M. (2016). The unattainable trifecta of urban agriculture. Journal of A griculture, F ood Systems, and Community D evelopment, 6(1), 14. https:/ / doi.org/ 10.5304/ jafscd.2015.061.014

Dig D eep Farms [DD F], Neideffer, M., Hargraves, M., \& Denning, C. (Producer). (2017). Dig D eep Farms in its larger context, a collaborative pathway model [Image]. Retrieved from the Food Dignity website: http:/ / www.fooddignity.org

Drake, L., \& Lawson, L. J. (2015). Results of a US and Canada community garden survey: Shared challenges in garden management amid diverse geographical and organizational contexts. A griaulture and $\mathrm{H}$ uman $\mathrm{V}$ alues, 32(2), 241-254. https:/ / doi.org/ 10.1007/ s10460-014-9558-7

East New York Farms! [ENY F], Vigil, D ., Hargraves, M., \& Denning, C. (2017). East New York Farms! A collaborative pathway model [Image]. Retrieved from the Food Dignity website: http:// www.fooddignity.org

Feeding Laramie Valley [FLV], Woodsum, G. M., Hargraves, M., \& D enning, C. (Producer). (2017). Feeding Laramie Valley: A collaborative pathway model [Image]. Retrieved from the Food Dignity website: http:/ / www.fooddignity.org

Feenstra, G. (2002). Creating space for sustainable food systems: Lessons from the field. A griculture and $\mathrm{H}$ uman $\mathrm{V}$ alues, 19(2), 99-106. https:/ / doi.org/ 10.1023/ A:1016095421310

Firth, C., Maye, D ., \& Pearson, D. (2011). D eveloping "community" in community gardens. L ocal E nvironment, 16(6), 555-568. https:// doi.org/ 10.1080/ 13549839.2011.586025

Food and Agriculture Organization of the United Nations [FAO]. (2002). The state of food insecurity in the world 2002. Rome. Retrieved from http:/ / www.fao.org/ docrep/ 005/ y7352e/ y7352e00.htm 
Journal of Agriculture, Food Systems, and Community D evelopment

ISSN: 2152-0801 online

https:/ / www.foodsystemsjournal.org

Food D ignity. (2015). Paths to F ood D ignity: D igital stories of personal journeys to food justiæ work [Video]. Retrieved from http:/ / www.tinyurl.com/ fooddignityplaylist

Gatto, N., Martinez, L., Spruijt-Metz, D ., \& D avis, J. (2017). LA Sprouts randomized controlled nutrition, cooking and gardening programme reduces obesity and metabolic risk in Hispanic/ Latino youth. Pediatric 0 besity, 12(1), 28- 37. https:// doi.org/ 10.1002/ oby.21077

Gittleman, M., Jordan, K., \& Brelsford, E. (2012). Using citizen science to quantify community garden crop yields. Cities and the E nvironment, 5(1), article 4. Retrieved from http:/ / digitalcommons.lmu.edu/ cate/ vol5/ iss1/ 4

Hallsworth, A., \& Wong, A. (2013). Urban gardening: A valuable activity, but. Journal of A griaulture, F ood Systems, and Community D evelopment, 3(2), 11-14. https:/ / doi.org/ 10.5304/ jafscd.2013.032.010

Hallsworth, A., \& Wong, A. (2015). Urban gardening realities: The example case study of Portsmouth, England. International Journal on F ood System D ynamics, 6(1), 1-11. https:// doi.org/ 10.18461/ ijfsd.v6i1.611

Hargraves, M., \& D enning, C. (2018). Visualizing expertise: Collaborative pathway modeling as a methodology for conveying community-driven strategies for change. Journal of A griculture, F ood Systems, and C ommunity D evelopment, 8(Suppl. 1), 101-115. https:/ / doi.org/ 10.5304/ jafscd.2018.08A.005

Hargraves, M., \& D enning, C. (2017). F ood D ignity C ollaborative Pathway M odels. Retrieved from http:/ / www.fooddignity.org/ collaborative-pathway-models

Hilchey, D . (Ed.). (2015). Commentaries on race and ethnicity in food systems work [Special issue]. Journal of A griculture, F ood Systems, and Community D evelopment, 5(4). Retrieved from https:/ / www.foodsystemsjournal.org/ index.php/ fsj/ issue/ view/ 21/ showToc

Hiza, H.A.B., \& Bente, L. (2007). N utrient content of the U.S. food supply, 1909-2004: A summary report (Home Economics Research Report No. 57). Washington, D C: U.S. D epartment of Agriculture, Center for Nutrition Policy and Promotion. Retrieved from http:// www.cnpp.usda.gov/ sites/default/ files/ nutrient content of the us food supply/ FoodSupply1909-2004Report.pdf

Holt-Giménez, E., \& Shattuck, A. (2011). Food crises, food regimes and food movements: rumblings of reform or tides of transformation? Journal of Peasant Studies, 38(1), 109-144. https:/ / doi.org/ 10.1080/ 03066150.2010.538578

Hou, J., Johnson, J., \& Lawson, L. J. (2009). G reening dities, growing ommunities: L earning from Seattle's urban community gardens. Seattle: Washington University Press.

Jones, V. (2009). The green collar economy: H ow one solution can fix our two biggest problems. New Y ork: Harper Collins.

La Via Campesina. (2010, D ecember 10). Via Campesina D eclaration in Cancún: The people hold thousands of solutions in their hands [Press Release]. Retrieved from http:/ / viacampesina.org/ en/ index.php/ actions-and-eventsmainmenu-26/-climate-change-and-agrofuels-mainmenu-75/ 984-via-campesina-declaration-in-cancun-the-peoplehold-thousands-of-solutions-in-their-hands

Lawson, L. J. (2005). City Bountiful: A century of ommunity gardening in A merica. Berkeley, CA: University of California Press.

Litt, J. S., Soobader, M. J., Turbin, M. S., Hale, J. W., Buchenau, M., \& Marshall, J. A. (2011). The influence of social involvement, neighborhood aesthetics, and community garden participation on fruit and vegetable consumption. A merican Journal of Public H ealth, 101(8), 1466-1473. https:/ doi.org/ 10.2105/ AJPH.2010.300111

Luotto, M. (Producer). (2015). T racing the paths: telling stories of F ood D ignity (short documentary) [Video]. Retrieved from http:/ / www.youtube.com/ watch?v=-KncokFttEM

Marshall, D . (Producer). (2015). My food justice story starts here. Paths to F ood D ignity [Video] Retrieved from http:/ / www.youtube.com/ watch?v=paPqBsIydHM

Meek, D., Bradley, K., Ferguson, B., Hoey, L., Morales, H., Rosset, P., \& Tarlau, R. (2017). Food sovereignty education across the Americas: Multiple origins, converging movements. A grialture and $\mathrm{H}$ uman $\mathrm{V}$ alues. Advance online publication. https:/ / doi.org/ 10.1007/ s10460-017-9780-1

Meinen, A., Friese, B., Wright, W., \& Carrel, A. (2012). Y outh gardens increase healthy behaviors in young children. Journal of $H$ unger \& E nvironmental N utrition, 7(2-3), 192-204. https:/ / doi.org/ 10.1080/ 19320248.2012.704662

Millennium Ecosystem Assessment. (2005). E cosystems and human well-being: Biodiversity synthesis. Washington, D C: World Resources Institute.

National Gardening Association. (2014). G arden to table: A five year look at food gardening in the U S. Retrieved from https:/ / garden.org/ special/ pdf/ 2014-NGA-G arden-to-Table.pdf 
Neideffer, M. (Producer). (2015). When good food makes for good policing. Paths to F ood D ignity. [Video]. Retrieved from http:/ / www.youtube.com/ watch?v=zuMNSA H6zlE

Nettle, C. (2014). C ommunity gardening as social action. Surrey, England: Ashgate.

O ber Allen, J., Alaimo, K., Elam, D ., \& Perry, E. (2008). G rowing vegetables and values: Benefits of neighborhoodbased community gardens for youth development and nutrition. Journal of $\mathrm{H}$ unger \& E nvironmental $\mathrm{N}$ utrition, 3(4), 418-439. https:/ / doi.org/ 10.1080/ 19320240802529169

Poppendieck, J. (1998). Sweet charity?: E mergency food and the end of entitlement. New York: Penguin.

Porter, C. M. (2018a). Triple-rigorous storytelling: A PI's reflections on devising case study methods with five community-based food justice organizations. Journal of A griculture, F ood Systems, and C ommunity D evelopment, 8(Suppl. 1), 37-61. https:/ / doi.org/ 10.5304/ jafscd.2018.08A.008

Porter, C. M. (2018b). What gardens grow: O utcomes from home and community gardens supported by communitybased food justice organizations. Journal of A griaulture, F ood Systems, and C ommunity D evelopment, 8(Suppl. 1), 187-205. https:// doi.org/ 10.5304/ jafscd.2018.08A.002

Potter, E. (Producer). (2015). G rowing gardens... and kids. Paths to F ood D ignity [Video]. Retrieved from https:// www.youtube.com/ watch?v=zuMNSAH6zlE

Pourias, J., D uchemin, E., \& Aubry, C. (2015). Products from urban collective gardens: Food for thought or for consumption? Insights from Paris and Montreal. Journal of A griaulture, F ood Systems, and Community D evelopment, 5(2), 175-199. https:/ / doi.org/ 10.5304/ jafscd.2015.052.005

Pudup, M. B. (2008). It takes a garden: Cultivating citizen-subjects in organized garden projects. G eoforum, 39(3), 12281240. https:/ / doi.org/ 10.1016/ j.geoforum.2007.06.012

Rucker, P. (Producer). (2015). Fresh start. Paths to F ood D ignity [Video] .Retrieved from http:// www.youtube.com/ watch?v=zuMNSAH6zlE

Saldivar-Tanaka, L., \& Krasny, M. (2004). Culturing community development, neighborhood open space, and civic agriculture: The case of Latino community gardens in New Y ork City. A griaulture and H uman V alues, 21(4), 399-412. https:// doi.org/ 10.1007/ s10460-003-1248-9

Saul, N., \& Curtis, A. (2013). The Stop: H ow the fight for good food transformed a community and inspired a movement. New York: Melville House.

Sbicca, J. (2012). G rowing food justice by planting an anti-oppression foundation: Opportunities and obstacles for a budding social movement. A griculture and $\mathrm{H}$ uman $\mathrm{V}$ alues, 29(4), 455-466. https:// doi.org/ 10.1007/ s10460-012-9363-0

Schupp, J. L., Som Castellano, R. L., Sharp, J. S., \& Bean, M. (2016). Exploring barriers to home gardening in O hio households. L ocal E nvironment, 21 (6), 752- 767. https:/ / doi.org/ 10.1080/ 13549839.2015.1017807

Sequeira, J. (Producer). (2015). Sankofa. Paths to F ood D ignity [Video]. Retrieved from http:/ / www.youtube.com/ watch?v=zuMNSAH6zlE

Seufert, V., Ramankutty, N., \& Foley, J. (2012). Comparing the yields of organic and conventional agriculture. N ature, 485(6), 229-232. https:/ / doi.org/ 10.1038/ nature11069

Smith, V., \& Harrington, J. (2014). Community food production as food security: Resource and market valuation in Madison, Wisconsin (USA). Journal of A griculture, Food Systems, and C ommunity D evelopment, 4(2), 61-80. https:// doi.org/ 10.5304/ jafscd.2014.042.006

Soga, M., Gaston, K. J., \& Y amaura, Y. (2017). G ardening is beneficial for health: A meta-analysis. Preventive M edicine Reports, 5, 92-99. https:/ / doi.org/ 10.1016/ j.pmedr.2016.11.007

Stevenson, G. W., Ruhf, K., Lezberg, S., \& Clancy, K. L. (2007). Warrior, builder, and weaver work: Strategies for changing the food system. In C. C. Hinrichs \& T. A. Lyson (Eds.), Remaking the N orth A merican food system: Strategies for sustainability (pp. 33-62). Lincoln: University of Nebraska Press.

Stroink, M. L., \& Nelson, C. H. (2009). Aboriginal health learning in the forest and cultivated gardens: Building a nutritious and sustainable food system. Journal of A gromediane, 14(2), 263-269.

https:/ / doi.org/ 10.1080/ 10599240902739737

Taylor, J. R., \& Lovell, S. T. (2014). Urban home food gardens in the Global North: Research traditions and future directions. A griculture and H uman V alues, 31(2), 285-305. https:/ / doi.org/ 10.1007/ S10460-013-9475-1 
Thrasher, D . (2016). Fumbling for community in a Brooklyn community garden. In J. C. Dawson \& A. Morales (Eds.), Cities of farmers: U rban agricultural practios and proesses (pp. 159-176). Iowa City: University of Iowa Press.

Twiss, J., D ickinson, J., D uma, S., Kleinman, T., Paulsen, H., \& Rilveria, L. (2003). Community gardens: Lessons learned from Califormia Healthy Cities and Communities. A merican Journal of Public $\mathrm{H}$ ealth, 93(9), 1435-1438. Retrieved from https:// www.ncbi.nlm.nih.gov/ pmc/ articles/ PMC1447988/

Vitiello, D ., \& Nairn, M. (2009). Community gardening in Philadelphia: 2008 harvest report. Retrieved from http:/ / www.farmlandinfo.org/ sites/ default/ files/ Philadelphia_Harvest_1.pdf

Vitiello, D ., Nairn, M., G risso, J. A., \& Swistak, N. (2010). C ommunity gardening in C amden, N J. H arvest report: Summer 2009. Retrieved from http:/ / camdenchildrensgarden.org/ Community\%20G ardening\%20Harvest\%20Report.pdf

White, M. M. (2011). D-Town Farm: African American resistance to food insecurity and the transformation of D etroit. E nvironmental Practice, 13(4), 406-417. https:/ / doi.org/ 10.1017/ S1466046611000408

Whole Community Project [WCP], Sequeira, E. J., Hargraves, M., \& D enning, C. (Producer). (2017). Whole Community Project: a collaborative pathway model. Food D ignity C ollaborative Pathway M odels. Retrieved from http:/ / www.fooddignity.org

Winne, M. (2008). Closing the food gap: Resetting the table in the land of plenty. Boston: Beacon Press.

Winne, M. (2010). F ood rebels, guerrilla gardeners, and smart-ook in' mamas: Fighting back in an age of industrial agriculture. Boston: Beacon Press.

Y in, R. K. (2009). C ase study research: D esign and methods (4th ed.). Thousand O aks, Califormia: SAGE.

Zanko, A., Hill, J. L., Estabrooks, P. A., Niewolny, K. L., \& Zoellner, J. (2014). Evaluating community gardens in a health disparate region: A qualitative case study approach. Journal of $\mathrm{H}$ unger \& E nvironmental N utrition, 9(2), 137-169. https:/ / doi.org/ 10.1080/ 19320248.2014.898171 